\title{
Nurseries surveyed in Southern California adopt best practices for water quality
}

\author{
by Salvatore S. Mangiafico, Julie Newman, \\ Maren Mochizuki, Dale Zurawski, \\ Donald J. Merhaut and Ben Faber
}

\section{$A$ variety of good management}

practices have been recommended to minimize the impact of water runoff from production nurseries. However, studies have not been conducted to gauge which management practices nursery producers are most likely to adopt in response to education and increased government oversight. We surveyed 85 production nurseries in Southern California about their existing practices to limit the impacts of runoff from their facilities. Of these, 65 in Ventura County were resurveyed with the same questionnaire within 2 years. The positive response rate for following good management practices was $65 \%$, compared to $57 \%$ in the initial survey. There were significant increases in every category of practices surveyed, and significant changes in the adoption of 38 specific practices. This suggests that nurseries are amenable to adopting management practices within a short time span in areas where there is increased governmental oversight and educational opportunities for growers.

alifornia's nursery and flower industries each rank among the top 10 agricultural commodities in the state, with a combined $\$ 3.8$ billion in sales in 2006 (CDFA 2007). California's nursery industry is the largest in the nation, and is concentrated particularly in the central and south-coast counties (CDFA 2007). The intense application of fertilizers, pesticides and irrigation water has made runoff from these facilities an environmental concern. Practices recommended to minimize potential pol-

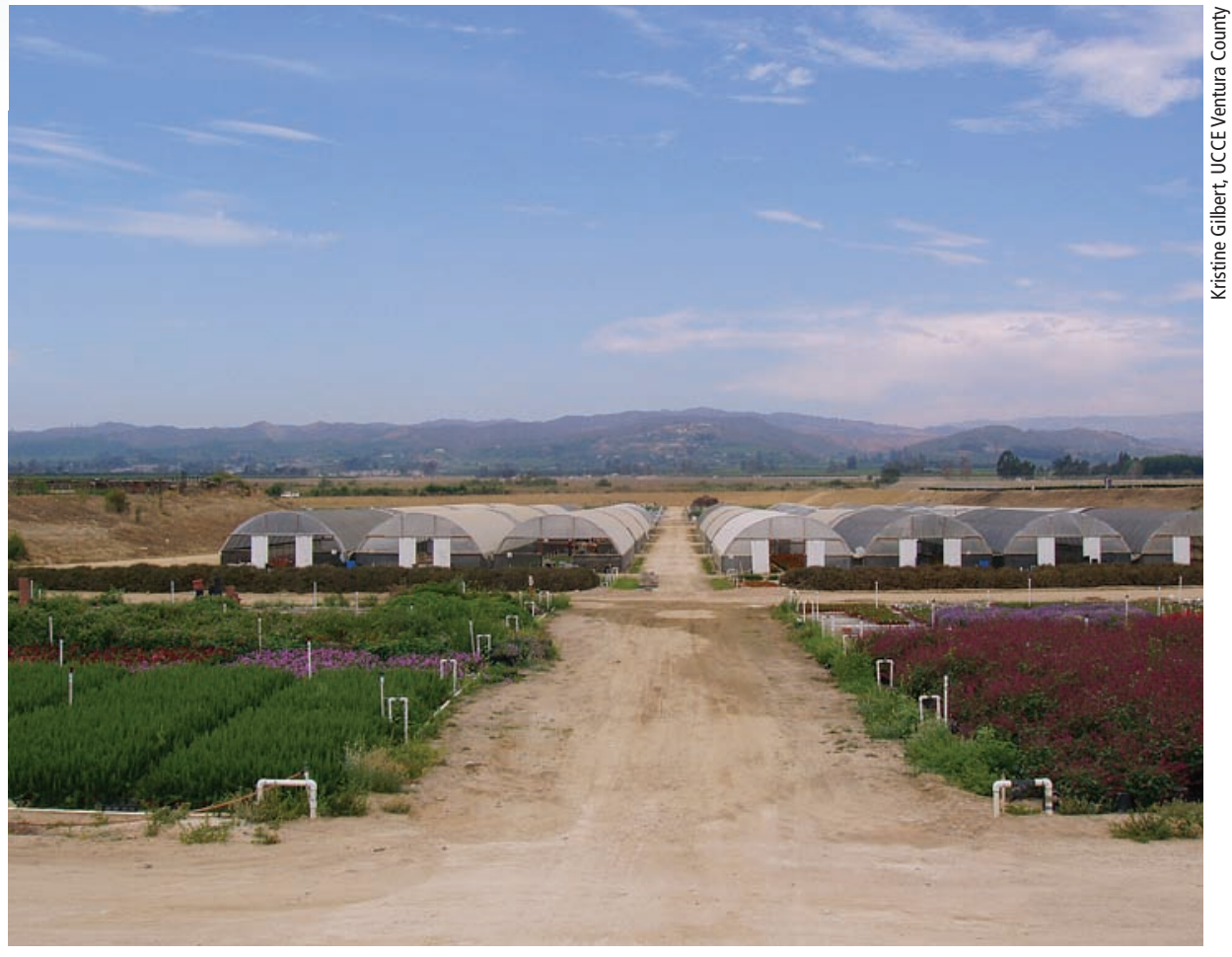

Nurseries in Southern California employ a variety of methods to produce a broad range of products. Eighty percent of the surveyed production area was uncovered, while the rest was in greenhouses and shadehouses, with numerous irrigation methods.

lution by water outflow from nurseries include proper management of fertilizers, pesticides and irrigation water, as well as technologies such as retention basins to collect runoff for treatment and reuse (Newman 2009). However, few studies have documented the extent to which production nurseries have adopted these management practices.

Some studies have found considerable adoption of selected management practices by nurseries. For example, surveys of U.S. container production nurseries in Alabama and Georgia found that about half or more captured runoff water, and more than half used vegetative filter strips (Fain et al. 2000; Garber et al. 2002). Other practices may be less commonly adopted. A survey of container nurseries in west-central Florida from 1999 to 2002 found that only $35 \%$ of respondents using overhead irrigation monitored their system's uniformity (Schoene et al. 2006).

Discovering deficiencies in the adoption of management practices to protect water quality may be valuable to guide future education and research efforts. However, studies have not been conducted to gauge which practices will be adopted by nursery producers in response to grower education and increased government oversight. In an earlier survey of Southern California nurseries, respondents said that environmental and governmental regulations had a lower impact on their businesses relative to economic and resource factors (Merhaut and Pittenger 2005), raising the question of whether such pressure will lead to the adoption of appropriate practices. Our study was conducted to characterize management practices relevant to waterquality protection at 85 Southern California production nurseries, and to determine changes in the adoption of improved practices in a climate of regulatory pressure and available educational resources at 65 production nurseries in Ventura County. 


\section{Self-assessment surveys}

We surveyed 65 nurseries in Ventura County and an additional 20 comparison nurseries in Los Angeles, Monterey, Riverside, San Bernardino, San Diego, San Luis Obispo, Santa Barbara and Santa Cruz counties. Surveys from Ventura County represented about $46 \%$ of all production nurseries in the county, and were conducted between January 2004 and September 2005. The same nurseries in Ventura County were then resurveyed with the same questionnaire between October 2005 and September 2006. The interval between the initial survey and the resurvey was between 12 and 21 months. For simplicity, the initial survey time period is referred to as "2004" and the resurvey as "2006."

Surveys from other counties were conducted in 2007 and 2008 and were not repeated. The survey was a 142-question self-assessment questionnaire (UCCE VC 2003) developed from an earlier self-assessment tool used in San Diego County (UCCE SDC). Questionnaires were typically completed during personal interviews with Cooperative Extension staff so that any questions could be addressed immediately. Responses were kept confidential to promote honesty and accuracy.

\section{Size and production methods}

In the first 10 questions, growers were asked about their production areas and methods. Differences between responses for Ventura County

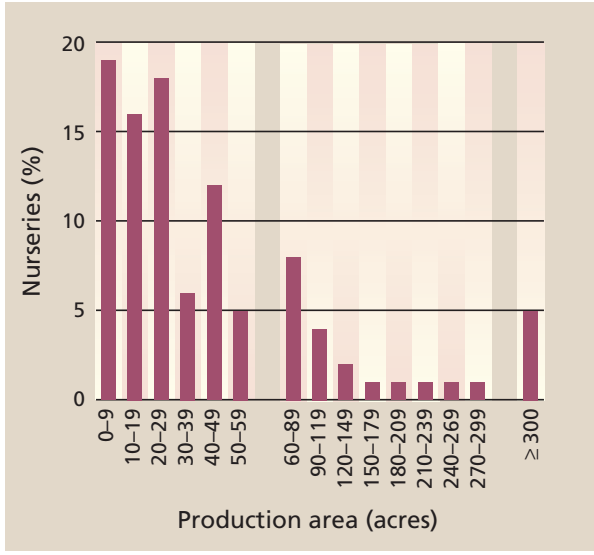

Fig. 1. Distribution by production area of surveyed nurseries in Southern California.

\section{Changes in practices could represent a substantial decrease in the potential contamination of surface water and groundwater from the participating operations.}

and those from other counties were tested with the Mann-WhitneyWilcoxon two-sample test. No significant differences $(P \geq 0.05)$ were found, suggesting that nurseries in Ventura County are similar to those throughout Southern California in terms of production area, products, irrigation practices and covered facilities.

Surveyed nurseries had production areas ranging from 0.25 to 290 acres ( 0.10 to 120 hectares), with a median of 15 acres (6.1 hectares). While the majority were relatively small, 11 (13\%) had production areas greater than 120 acres (fig. 1). Sixty-nine percent of the total area produced outdoor container nursery stock, and 14\% produced cut flowers. A small percentage of area was devoted to plant propagation $(6 \%)$, bedding plants $(7 \%)$ and potted plants for indoor use (4\%). Most production area was uncovered (80\%); the rest was in greenhouses $(12 \%)$ and shadehouses (9\%) (note slight rounding error). Lowvolume irrigation was the most common irrigation method ( $51 \%$ of total surveyed production area), overhead irrigation was the second most common (30\%) and hand-watering accounted for $18 \%$ of production area.

\section{Management practices}

The rest of the questions (132) were grouped into nine categories deal- ing with good management practices, including irrigation, leaching, runoff, field soil, container media, nutrient assessment, fertilizer, pest management and general property management (table 1). For these questions respondents were able to answer "yes," indicating that the practice had been implemented at their operation; "no," indicating that it had not been implemented but the practice was applicable; or "not applicable," indicating that it was not applicable to their operation. For example, collecting irrigation runoff would not be applicable at operations that do not produce irrigation runoff, nor would field soil practices be applicable when the entire crop is grown in containers. Not all recommended practices are desirable, depending on sitespecific operations. Therefore, a "no" response did not necessarily indicate a deficiency. In general, though, a "yes" response indicated that a good management practice had been implemented.

Changes in responses from the initial survey to the resurvey for the Ventura County nurseries were assessed two different ways. For calculating changes within categories, "yes" responses were pooled and a repeatedmeasures analysis of variance (ANOVA) was performed. A significant positive result indicated a significant increase in "yes" responses.

\begin{tabular}{|c|c|c|c|c|c|c|}
\hline \multicolumn{7}{|c|}{$\begin{array}{l}\text { TABLE 1. Summary of responses to self-assessment survey }(2004) \text { and resurvey (2006) } \\
\text { for Ventura County production nurseries }(n=65)\end{array}$} \\
\hline \multirow[b]{2}{*}{$\begin{array}{l}\text { Management } \\
\text { question category }\end{array}$} & \multirow[b]{2}{*}{ Questions } & \multicolumn{2}{|c|}{ Yes responses } & \multirow[b]{2}{*}{ Significance } & \multirow{2}{*}{$\begin{array}{l}\text { Resurvey "not } \\
\text { applicable" } \\
\text { responses }\end{array}$} & \multirow{2}{*}{$\begin{array}{c}\text { Questions } \\
\text { with significant } \\
\text { change }\end{array}$} \\
\hline & & $\begin{array}{l}\text { Initial } \\
(2004)\end{array}$ & $\begin{array}{c}\text { Resurvey } \\
\text { (2006) }\end{array}$ & & & \\
\hline & no. & $\ldots \ldots$ & $\% \ldots$ & P value less than & $\%$ & no. \\
\hline Irrigation & 26 & 58 & 66 & 0.0001 & 18 & 7 \\
\hline Leaching & 4 & 32 & 34 & 0.01 & 46 & 3 \\
\hline Runoff & 6 & 10 & 20 & 0.01 & 43 & 5 \\
\hline Field soil & 6 & 27 & 32 & 0.05 & 56 & 0 \\
\hline Container media & 3 & 52 & 66 & 0.0001 & 9 & 2 \\
\hline Nutrient assessment & 5 & 64 & 73 & 0.01 & 5 & 1 \\
\hline Fertilizer & 11 & 67 & 71 & 0.01 & 21 & 4 \\
\hline Integrated pest & 33 & 62 & 70 & 0.0001 & 16 & 7 \\
\hline Property & 39 & 64 & 71 & 0.0001 & 19 & 9 \\
\hline All & 133 & 57 & 65 & 0.0001 & 21 & 38 \\
\hline
\end{tabular}




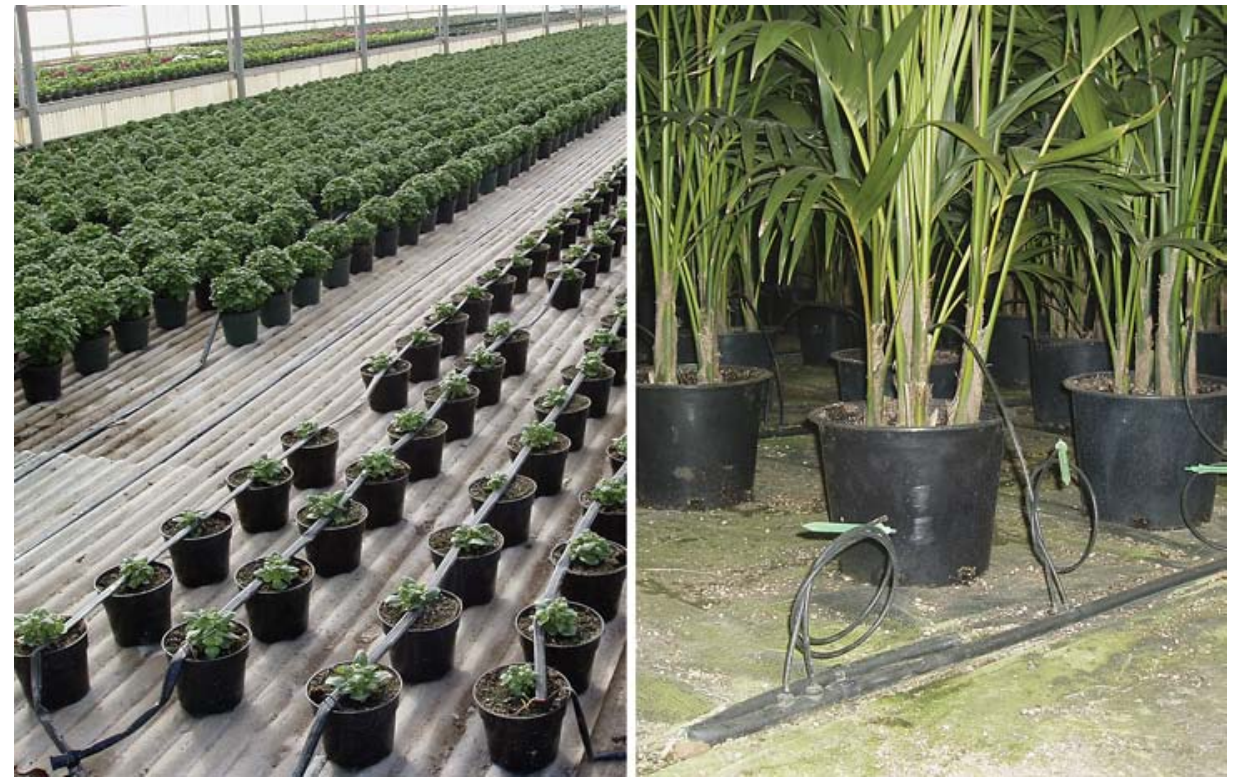

Drip tape, left, and microirrigation stakes, right, are low-volume irrigation methods. In Southern California, $51 \%$ of surveyed production areas employed a low-volume irrigation method. When properly scheduled, such methods are effective in preventing runoff.

\begin{tabular}{|c|c|c|c|c|c|}
\hline \multicolumn{6}{|c|}{$\begin{array}{l}\text { TABLE 2. Questions and responses concerning leaching management from } \\
\text { self-assessment questionnaire for Ventura County production nurseries }(n=65)\end{array}$} \\
\hline \multirow[b]{2}{*}{ Runoff management question } & \multirow[b]{2}{*}{ Year } & \multicolumn{3}{|c|}{ Response } & \multirow{2}{*}{$\begin{array}{l}\text { Significance } \\
\text { of change }\end{array}$} \\
\hline & & Yes & No & Not applicable & \\
\hline & & \multicolumn{3}{|c|}{$\ldots \ldots \ldots \ldots \% \cdots \cdots$} & $\mathrm{P}$ value $<$ \\
\hline \multirow{2}{*}{$\begin{array}{l}\text { 36. Are specific factors, such as electrical conductivity } \\
\text { (EC) of root media or leachates, used to determine } \\
\text { leaching practices (i.e., deliberately overwatering to } \\
\text { flush salts) as part of the irrigation schedule? }\end{array}$} & 2004 & 42 & 32 & 26 & \\
\hline & 2006 & 43 & 18 & $38^{*}$ & 0.05 \\
\hline \multirow{2}{*}{$\begin{array}{l}\text { 37. Are irrigation schedules set to perform leaching } \\
\text { at specific irrigation events, rather than every time } \\
\text { irrigation is performed? }\end{array}$} & 2004 & 31 & 34 & 35 & \\
\hline & 2006 & 35 & 15 & 49 & 0.01 \\
\hline \multirow{2}{*}{$\begin{array}{l}\text { 38. Is leaching performed only with fertilizer } \\
\text { injectors turned off? }\end{array}$} & 2004 & 38 & 17 & 45 & Not \\
\hline & 2006 & 35 & 12 & 52 & significant \\
\hline \multirow{2}{*}{$\begin{array}{l}\text { 39. Has the amount of leaching that occurs been } \\
\text { measured? }\end{array}$} & 2004 & 17 & 45 & 38 & \\
\hline & 2006 & 23 & 34 & 43 & 0.05 \\
\hline
\end{tabular}

\begin{tabular}{|c|c|c|c|c|c|}
\hline \multicolumn{6}{|c|}{$\begin{array}{l}\text { TABLE 3. Questions and responses concerning runoff management from } \\
\text { self-assessment questionnaire for Ventura County production nurseries }(n=65)\end{array}$} \\
\hline \multirow[b]{2}{*}{ Leaching management question } & \multirow[b]{2}{*}{ Year } & \multicolumn{3}{|c|}{ Response } & \multirow{2}{*}{$\begin{array}{l}\text { Significance } \\
\text { of change }\end{array}$} \\
\hline & & Yes & No & Not applicable & \\
\hline & & \multicolumn{3}{|c|}{$\ldots \ldots \ldots \ldots \ldots \ldots$} & P value $<$ \\
\hline \multirow{2}{*}{$\begin{array}{l}\text { 40. Is irrigation runoff collected from production } \\
\text { areas? }\end{array}$} & 2004 & 11 & 66 & 23 & \\
\hline & 2006 & 22 & 42 & $37 *$ & 0.05 \\
\hline \multirow[t]{2}{*}{ 41. Is collected irrigation water recycled? } & 2004 & 6 & 42 & 52 & \\
\hline & 2006 & 14 & 29 & 57 & 0.001 \\
\hline \multirow{2}{*}{$\begin{array}{l}\text { 42. Are collection reservoirs/tanks managed to avoid } \\
\text { overflow during both dry and wet weather? }\end{array}$} & 2004 & 8 & 25 & 68 & Not \\
\hline & 2006 & 23 & 12 & 65 & significant \\
\hline \multirow{2}{*}{$\begin{array}{l}\text { 43. Is runoff water quality regularly monitored, } \\
\text { either by growing operation personnel or } \\
\text { professionally by a lab? }\end{array}$} & 2004 & 12 & 60 & 28 & \\
\hline & 2006 & 17 & 40 & 43 & 0.01 \\
\hline \multirow[t]{2}{*}{ 44. Are runoff water-quality records maintained? } & 2004 & 8 & 55 & 37 & \\
\hline & 2006 & 17 & 34 & 49 & 0.01 \\
\hline \multirow[t]{2}{*}{ 45. Is storm water collected? } & 2004 & 15 & 78 & 6 & \\
\hline & 2006 & 26 & 66 & 8 & 0.01 \\
\hline
\end{tabular}

One limitation was that "not applicable" responses were not distinguished from "no" responses in the analyses. To calculate changes in responses for individual questions, a repeated measures test for marginal homogeneity was performed for each question. This analysis detects differences in the relative frequencies of "yes," "no" and "not applicable," but a significant result doesn't necessarily indicate an increase in "yes" responses.

Irrigation. The 26 irrigation questions covered practices such as monitoring irrigation water quality, maintaining systems, and the scheduling of timing and amounts. Ventura County nurseries commonly followed good management practices for irrigation management. The percentage of "yes" responses was $66 \%$ in 2006, with $18 \%$ "not applicable" (table 1). More than $90 \%$ maintained their irrigation systems, assigned personnel for irrigation, grouped plants by watering requirements and adjusted watering schedules to meet plant needs (data not shown), with similar results in 2004. Compared with 2004, significantly more respondents performed distribution uniformity evaluations in 2006 (from $29 \%$ to $48 \%$ ), used pot weights or other measurements to determine irrigation schedules (22\% to $43 \%$ ) or adjusted overhead irrigation to prevent overspray (40\% to 54\%). For pooled responses, the number of "yes" responses significantly increased from $58 \%$ to $66 \%$ (table 1).

Leaching. The four questions in the leaching management category covered the scheduling and amount of water applied to leach salts from the root zone. The percentage of positive responses was 34\% in 2006, a significant 2\% increase from 2004 (table 1). This increase was attributable to changes in response to three of the four questions (table 2), including increased use of electrical conductivity measurements to determine leaching practices, increased avoidance of leaching at every irrigation event and an increase in measuring the amount of leachate. There was no significant change $(P \geq 0.5)$ in the number of nurseries practicing leaching with fertilizer injectors turned off. 


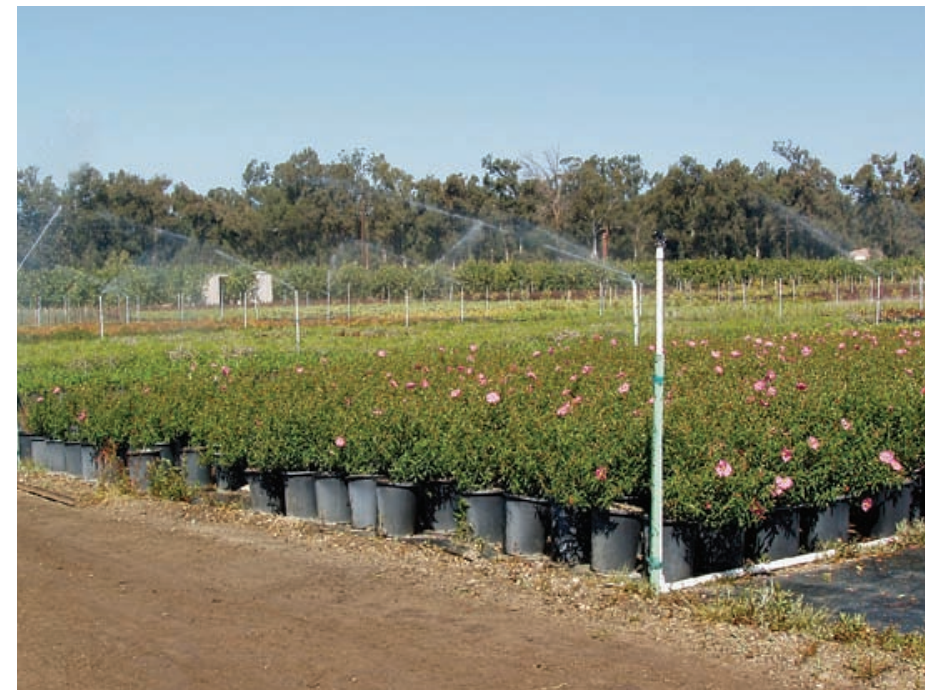

Overhead irrigation was used in $30 \%$ of the surveyed production area. If containers are not closely spaced, a significant portion of the applied water falls between containers and is wasted as runoff.

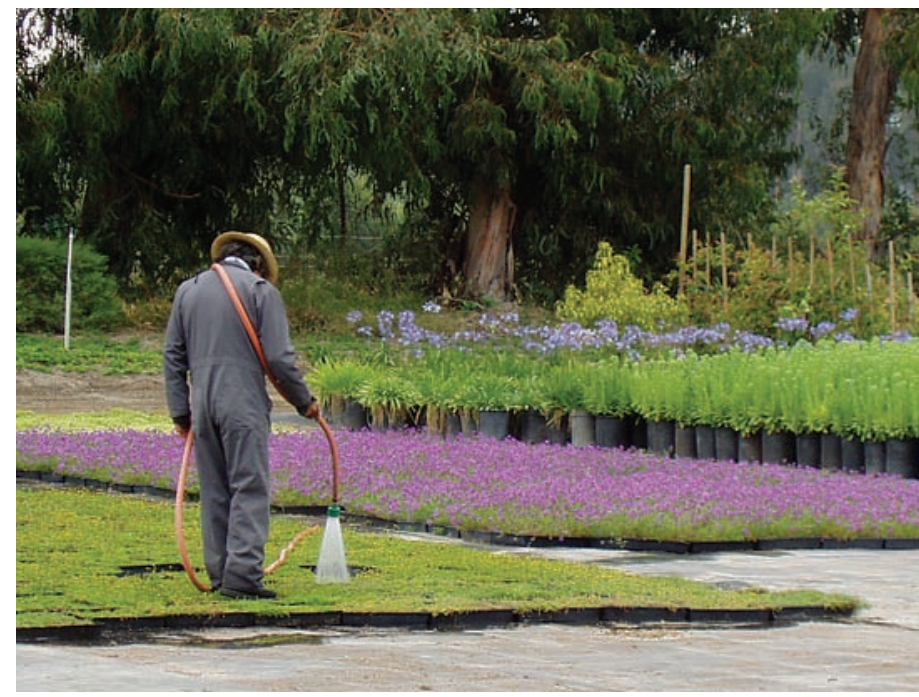

Hand-watering accounted for $18 \%$ of the production area in surveyed nurseries. Experienced personnel are necessary to avoid overwatering, and an on/off valve is recommended.
Runoff. The six questions in the runoff management category covered the collection and recycling of irrigation and storm-water runoff. Good management practices were not common, but their adoption increased from the initial survey to the resurvey in 2006. Pooled "yes" responses were only $10 \%$ in 2004 , but increased significantly to $20 \%$ in 2006 , with $43 \%$ "not applicable" (table 1).

Responses to five out of six questions changed significantly from 2004 to 2006 (table 3). Specifically, the frequency of runoff collection doubled (11\% to $22 \%$ ), the recycling of runoff water doubled (6\% to $14 \%)$ and run- off water-quality monitoring ( $12 \%$ to $17 \%$ ) and record keeping (8\% to $17 \%$ ) increased. The adoption of runoff management practices was low compared with surveys in Alabama, Georgia and Florida, which found that 75\%, 45\% and $50 \%$ of nurseries, respectively, collected runoff (Fain et al. 2000; Garber et al. 2002; Schoene et al. 2006).

Field soil. The six questions in the field-soil management category concerned managing soil erosion, applying soil amendments, and using cover crops and mulches. Many container nurseries had no area in field production, leading to 56\% "not applicable" compared with
32\% "yes" responses (table 1). While the change in responses was not significant for any individual question, the pooled number of "yes" responses increased significantly from $27 \%$ to $32 \%$ (table 1).

Container media. The three questions in the container-media management category concerned mixing potting media in a sheltered area, measuring mediawater holding capacity and the use of wetting agents. Good practices for container-media management were commonly adopted, with 66\% "yes" and 9\% "not applicable" responses in 2006. The number of positive responses increased significantly from 2004 (table 1). Specific

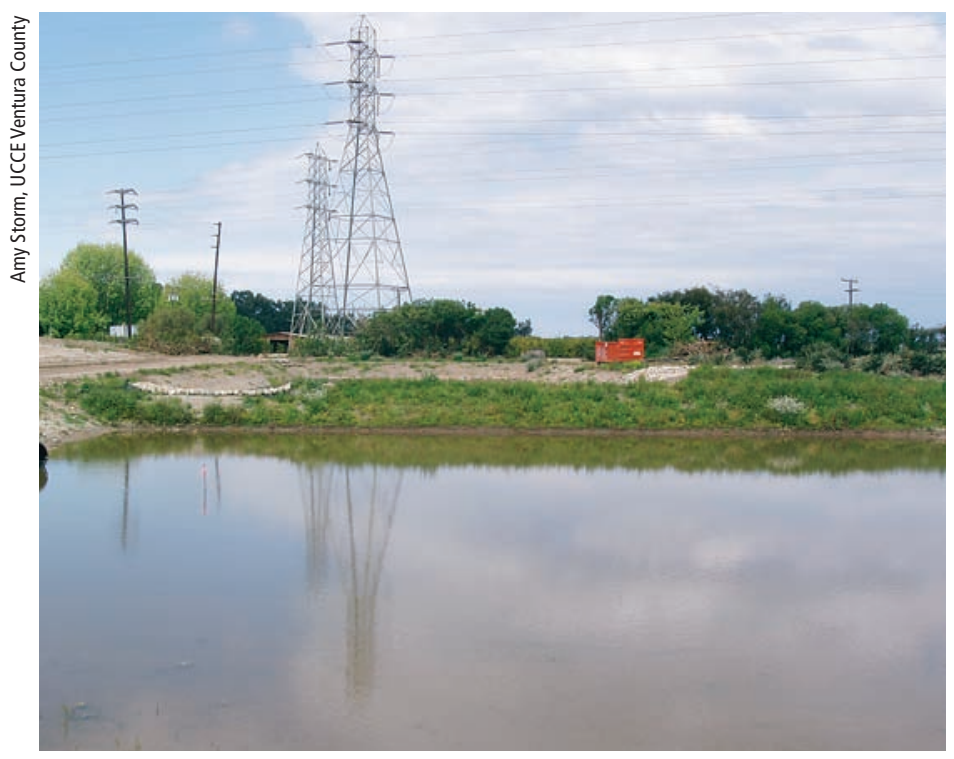

The unlined bottom of this detention basin allows captured runoff to percolate slowly into the ground. Soils and vegetation remove some contaminants from the water as it percolates or is taken up by plants.

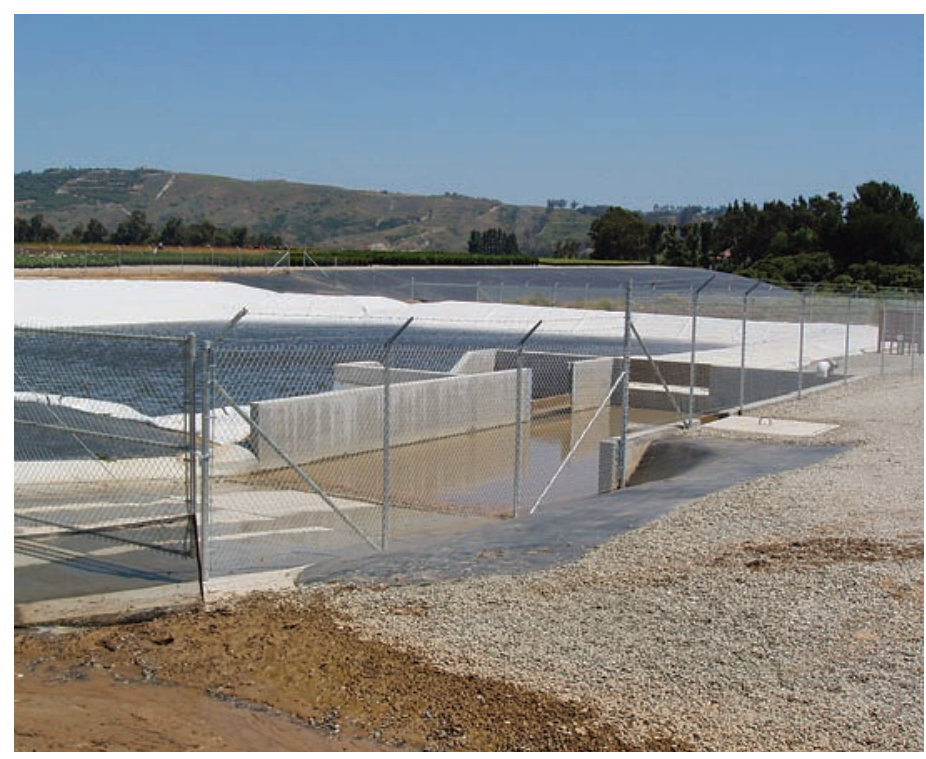

A retention basin allows runoff to be treated and recycled for use as irrigation water. Ventura County nurseries that recycle irrigation runoff significantly increased from $6 \%$ in 2004 to $14 \%$ in 2006. 
management practices that improved were testing media for water-holding capacity (51\% to $71 \%$ ) and considering the use of wetting agents (38\% to 57\%) (data not shown).

Nutrients, fertilizers, pest management and property management.

Questions in the nutrient, fertilizer and pest management categories covered practices including soil and plant tissue testing, the application of fertilizer at proper rates, monitoring to assess disease and pest populations, and the proper application of pesticides. Questions in the property management category covered practices that included preventing water pollution by fuels, trash and sewage. The adoption of good management practices in these categories was common, with the frequency of "yes" responses in each category significantly increasing from greater than $60 \%$ in 2004 to greater than $70 \%$ in 2006 (table 1). More respondents accounted for nutrients in irrigation water or composts (from 57\% to 77\%) (data not shown), tested nutrient levels in fertigation water $(63 \%$ to $68 \%)$ and used impermeable surfaces for fertilizer storage (58\% to $72 \%$ ) and mixing (57\% to $69 \%$ ). In the integrated pest management category, practices with significant changes included the use of diagnostic labs (66\% to $78 \%)$, the calibration of spraying equipment ( $74 \%$ to $85 \%$ ) and the use of plant quarantines $(26 \%$ to $48 \%$ ). In the property management category, more respondents managed nonproduction areas to prevent erosion and runoff $(68 \%$ to $86 \%)$ and made spill kits available (60\% to $72 \%$ ).

\section{Comparison of nurseries}

Within good management question categories, no significant $(P \geq$ 0.05 ) differences were found between Ventura County nurseries and the other Southern California counties (data not shown). Similarly, no significant differences were found when all management practice questions were pooled. This suggests that surveyed nurseries in Ventura County were similar to nurseries elsewhere in the region in terms of the extent to which they adopted good management practices. If it is the case that nurseries are similar among counties, education programs could be developed for regionwide application instead of for specific counties.

There were significant increases in positive responses in every good management category for Ventura County nurseries between surveying in 2004 and resurveying in 2006, as well as significant changes in responses for 38 out of 132 good management practices. This indicates that nurseries can become amenable to the adoption of such practices within a relatively short time frame.

\section{Best management practices}

These changes in practices could represent a substantial decrease in the potential contamination of surface water and groundwater from participating operations. We did not determine the causes for the increased adoption of good management practices. However, during the interval between the survey and resurvey, at least 54 of the 85 growers $(63 \%)$ attended UC Cooperative Extension education programs in either English or Spanish, attended tours of nurseries implementing good management practices or interacted with Cooperative Extension staff during site visits.

Furthermore, completing the survey itself served as an educational tool for growers to evaluate their operations and learn about practices that help protect water resources. Participation in educational programs may be a factor in increasing growers' adoption of such practices. Increased governmental regulation of runoff from nurseries and other agriculture in this region may also have prompted growers to change. State and regional water-quality control boards and county agricultural commissioners implemented new regulatory requirements, which varied by county. Question categories in which respondents did not report a high rate of adoption - such as leaching and runoff management - merit increased educational efforts to further the adoption of good management practices in the nursery and flower industries.
S.S. Mangiafico is Environmental and Resource Management Agent, Rutgers University Cooperative Extension, Salem County, N.J., formerly Postdoctoral Scholar, Department of Environmental Sciences, UC Riverside; J. Newman is Farm Advisor, M. Mochizuki is Staff Research Associate, and D. Zurawski is Staff Research Associate, UC Cooperative Extension (UCCE), Ventura County; D.J. Merhaut is Cooperative Extension Specialist, Department of Botany and Plant Sciences, UC Riverside; and B. Faber is Farm Advisor, UCCE Ventura County.

Funding was provided by the California State Water Resources Control Board in accordance with the Costa-Machado Water Act of 2000 and the California Proposition 50 ballot initiative of 2002. We thank UCCE Farm Advisors Valerie Mellano, Karen Robb and Dave Shaw for their self-assessment questionnaire for San Diego greenhouses and container nurseries, which we adapted for this study.

\section{References}

[CDFA] California Department of Food and Agriculture. 2007. California Agricultural Resource Directory. Agricultural Statistical Review. http://www.cdfa.ca.gov/files/pdf/card/ ResDir07_Overview.pdf.

Fain GB, Gilliam CH, Tilt KM, et al. 2000. Survey of best management practices in container production nurseries. J Env Hortic 18:142-4.

Garber MP, Ruter JM, Midcap JT, Bondari K. 2002. Survey of container nursery irrigation practices in Georgia. HortTechnology 12:727-31.

Merhaut DJ, Pittenger D. 2005. Marketing trends and business management practices for the wholesale nursery industry in California. HortTechnology 15:381-5.

Newman JP (ed.). 2009. Greenhouse and Nursery Management Practices to Protect Water Quality. UC ANR Pub 3508. Oakland, CA. $160 \mathrm{p}$.

Schoene G, Yeager T, Haman D. 2006. Survey of container nursery irrigation practices in west-central Florida: An educational opportunity. HortTechnology 16:682-5.

[UCCE SDC] UC Cooperative Extension, San Diego County. (No date.) Runoff \& Nonpoint Source Pollution Self-assessment: Greenhouses \& Container Nurseries. http://cesandiego. ucdavis.edu/files/8455.pdf.

[UCCE VC] UC Cooperative Extension, Ventura County. 2003. Checklist for assessing and mitigating runoff in greenhouses and nurseries. http://ceVentura.ucdavis.edu/files/54712.pdf. 